\title{
Firewood extraction affects carbon pools and nutrients in remnant fragments of temperate forests at the Mexican Transvolcanic Belt
}

\author{
La extracción de leña afecta los almacenes de carbono y nutrientes en fragmentos de bosques \\ templados en el Eje Transvolcánico Mexicano
}

\author{
Felipe García-Oliva a*, Sara Covaleda ${ }^{\text {b,d }}$, Juan F Gallardo ${ }^{\text {b }}$, Christian Prat c, \\ Rodrigo Velázquez-Durán ${ }^{\text {, }}$, Jorge D Etchevers ${ }^{e}$
}

\author{
*Corresponding author: ${ }^{a}$ Universidad Nacional Autónoma de México, Centro de Investigaciones en Ecosistemas, AP 27-3, \\ Santa María de Guido, Morelia 58090, Michoacán, México, tel. +52-443-3222715, fax: +52-443-3222719, fgarcia@cieco.unam.mx \\ ${ }^{\mathrm{b}}$ C. S. I. C., IRNASa, Salamanca, España. \\ ' LPED, UMR151 AMU / IRD, Marseille, France. \\ ${ }^{\mathrm{d}}$ Colegio de la Frontera Sur, San Cristóbal de las Casas, México, scovadela@gmail.com \\ ${ }^{\text {e }}$ Colegio de Postgraduados de Montecillo, Departamento de Recursos Naturales, Texcoco, México.
}

\begin{abstract}
SUMMARY
Globally, remnant fragments of forests represent the main carbon reservoir of terrestrial ecosystems, but they suffer strong degradation due to uncontrolled wood extraction mainly by tree cut for household fuel use and charcoal production. The present study evaluates the degradation caused by wood extraction on carbon pools and soil nutrient dynamics in temperate forests distributed in remnant fragments located in central Mexico. Four sites with different intensity of wood extraction were chosen for measuring carbon pools and nutrient fluxes during two years. Both, aboveground carbon biomass and soil organic carbon values decreased with the intensity of forest degradation. The degraded forest (DF) showed total carbon content $55 \%$ lower than that shown by the seminatural forest (SF). Additionally, litterfall production was reduced in DF as compared to SF; the decomposition rate of standing litter was higher in the latter site. As a consequence, DF had lower organic matter inputs to the soil than that presented by SF. Soil extractable ammonium and microbial biomass- carbon and -nitrogen were lower in DF than in SF. It was concluded that the uncontrolled wood extraction in these remnants of temperate forest in Mexico significantly reduced the carbon pools, carbon and nutrient fluxes through litterfall and consequently, the soil nutrient dynamics were disrupted.
\end{abstract}

Key words: forest degradation, litterfall production, litter decomposition, microbial biomass, oak-pine forest.

\section{RESUMEN}

Globalmente, los fragmentos forestales representan un almacén importante de carbono, pero estos fragmentos están bajo una fuerte presión de degradación; principalmente, debido a la extracción ilegal de madera para leña y carbón vegetal. El presente estudio evaluó el efecto de la extracción de leña sobre los almacenes de carbono y la dinámica de nutrientes del suelo en bosques templados de fragmentos remanentes en el centro de México. Se estudiaron cuatro sitios con diferente grado de intensidad de extracción de leña, donde se midieron el carbono almacenado y el flujo de nutrientes durante dos años consecutivos. El carbono en la biomasa aérea y en el suelo se redujo con el aumento de la intensidad de la extracción. El bosque degradado (DF) presentó 55 \% menos contenido total de carbono que el bosque seminatural (SF). Así mimo, la producción de hojarasca también se redujo en el DF, pero la descomposición del mantillo fue mayor en el SF. Como consecuencia, el DF presentó menores entradas de carbono orgánico al suelo. El amonio disponible, el carbono y nitrógeno en la biomasa microbiana del suelo también fueron menores en el DF. La conclusión de este trabajo es que la extracción de leña en los fragmentos forestales en México reduce drásticamente las cantidades de carbono almacenado, los flujos de carbono y nutrientes por medio de la hojarasca, y por tanto, la dinámica de los nutrientes del suelo es afectada.

Palabras clave: degradación forestal, producción de hojarasca, descomposición de mantillo, biomasa microbiana, bosque pino-encino.

\section{INTRODUCTION}

Forest soils are the main carbon reservoir in terrestrial ecosystems and play an important role in global carbon cycling (García-Oliva and Masera 2004, Lal 2005). Deforestation strongly decreases carbon pools, promoting carbon emissions to the atmosphere. In Mexico, defores- tation produced $10 \%$ of the total national greenhouse gases emissions during 2006, representing $70.2 \mathrm{Tg} \mathrm{CO}_{2}$ eq (INE 2009). In the same way, forest management could also reduce carbon pools depending on the forest management strategies used. Jandl et al. (2007) reviewed the experimental evidence of the effect of specific forest management strategies on soil organic carbon sequestration. 
These authors concluded that forest management directly influences carbon pools by disrupting the balance between input and output carbon fluxes, although soil organic carbon (SOC) stabilization depends mainly on soil properties. For example, forest floor carbon stocks decreased with increasing thinning intensity by modifying soil microclimate and litterfall production (Jandl et al. 2007).

The increment of soil temperature with thinning intensity promotes SOC decomposition (Piene and Van Cleve 1978, Negrete-Yankelevich et al. 2007), while the reduction of litterfall production decreases carbon input to the soil (Vesterdal et al. 1995). However, carbon losses are compensated by forest productivity when the thinning interval is longer and with lower intensity (Jandl et al. 2007), as González-Espinosa et al. (1991) and Negrete-Yankelevich et al. (2007) reported a canopy recovery after 15 years of succession in several tropical mountain cloud forests in Mexico. Similarly, carbon pools reduction is observed if the residues are removed after forest harvesting by disturbing soil and changing microclimate (Jandl et al. 2007). In several countries it was reported that in afforestation (forest plantations) with short rotations, harvesting SOC losses were correlated directly with declines in plantation productivity (Johnson 1992, Evans 1996, Fox 2000). Covington (1981) reported that SOC was reduced around $50 \%$ after harvesting within the first 20 years, though it could be recovered during the re-growth of vegetation. In contrast, if the harvesting is deferred carefully, SOC is not affected (Lal 2005). Similarly, Johnson and Curtis (2001) estimated a reduction of $6 \%$ in SOC after harvest residues removal; nonetheless, SOC could increase in $18 \%$ if the residues were left in the site. Consequently, adequate forest management could have no negative impact on ecosystem carbon pools; moreover it could improve carbon sequestration.

In several countries, forest fragments are strongly used for providing household fuel wood. In these countries nearly $80 \%$ of the wood removed is used as a primary source of energy (IEA 2000), and charcoal is commonly used as fuel in developing countries around the world (Glaser et al. 2002, Vázquez-Marrufo et al. 2003). In many of these forest fragments, the removal of wood for fuel at low and constant rates drives to forest degradation (i.e., due to a reduction in tree biomass, tree density, etc.), and in most cases, illicit logging removes amounts of biomass comparable to legal cut (World Bank 1995). In Mexico, $15 \%$ of total population cooks with wood (INEGI 2010), suggesting a high demand of this fuel obtained from remnant forest fragments. For example, Ghilardi et al. (2009) estimated that $8 \%$ of the total forest area in the Purepecha region (central Mexico) is subjected to fuel wood extraction with a non-renewable basis. In spite of the high wood demand for fuel, there are few studies that evaluate carbon pool changes in remnant forests as a consequence of fuel wood extraction.

The forest fragments in the Cuitzeo basin in central Mexico represent an opportunity to evaluate the effect of forest degradation on ecosystem carbon pools under firewood extraction. These fragments are affected by the two following factors: a) conversion of forest to agricultural land (López et al. 2006); and b) the increment of legal and illegal fuel wood extraction by increasing charcoal demand from Morelia city (Aguilar et al. 2012). It has been widely reported that the conversion of forest to agricultural land decreased the ecosystems carbon pools (Guo and Gifford 2002, Murty et al. 2002), however there is scarce information on how wood extraction affects the carbon pools of volcanic soils of the temperate forest ecosystems located in high altitudes of geographical tropical countries. Furthermore, the effect of forest management on the soil dynamic of carbon, nitrogen and phosphorus has not been studied in an integrated manner in these scarce studies.

Therefore, the objective of the present study is to evaluate the effect of forest degradation on ecosystem carbon pools and on soil phosphorus and nitrogen dynamics in remnant temperate forest fragments of the Cuitzeo basin in the central plateau of Mexico.

\section{METHODS}

Study area. The study site is located in the Atécuaro catchment within the Cuitzeo basin, $12 \mathrm{~km}$ South from Morelia City (State of Michoacán, Mexico: 19³ 34' N; 101 10’ W). The climate type is Cwig according to Köppen. The average annual temperature is $17^{\circ} \mathrm{C}$, with May as the hottest $\left(19^{\circ} \mathrm{C}\right)$ and January as the coldest months $\left(13^{\circ} \mathrm{C}\right)$, and an annual mean precipitation of $844 \mathrm{~mm}$, concentrated from June to October. Associations of Andosols, Cambisols and Acrisols in the down slope are the dominant soils within the catchment, comprising the $70 \%$ of the total surface area (Covadela et al. 2009). Pine-oak forest fragments are distributed in altitudes ranging between 2,300 and 2,500 m a.s.l. along moderate to steep slopes. Study sites were selected from pine-oak forest fragments growing on an Andosol with different degradation intensity as a consequence of continuous timber and resin extraction: seminatural forest, forest with low degradation, forest burned in 1998, and degraded forest. The dominant tree species in the four sites were Quercus candicans Née, Q. obtusata Humb. and Bonpl., Tilia mexicana Schlecht., and Pinus pseudostrobus Lindley (Covadela et al. 2009). Table 1 shows some characteristics of the four studied forest sites.

Measurements and sampling. In each site, a $400 \mathrm{~m}^{2}$ circular plot was established in the middle of the forest fragment for avoiding edge effects (at least $100 \mathrm{~m}$ from the fragment edge). As a consequence of the size of forest fragments, only one plot could be established by site. Each circular plot design was created following the methods used by the Comisión Nacional Forestal de Mexico (2004) for the national forest and soil inventories (INFYS). Within each plot, the diameter at $1.3 \mathrm{~m}$ above ground (DBH) was measured for all trees taller than $1.30 \mathrm{~m}$. 
Table 1. Characteristics of four forest sites in the Cuitzeo basin, Mexico (Covadela et al. 2009). SF: seminatural forest, LF: forest with low degradation, BF: burned forest, DF: degraded forest. *Bulk density from A1 horizon. ** According to WRB (2007).

Características de los cuatro sitios en la cuenca de Cuitzeo, México (Covadela et al. 2009). SF: bosque seminatural, LF: bosque con poca degradación, BF: bosque quemado, DF: bosque degradado. *Densidad aparente del horizonte A1. ** De acuerdo a WRB (2007).

\begin{tabular}{|c|c|c|c|c|}
\hline Forest sites & SF & LF & $\mathrm{BF}$ & DF \\
\hline \multicolumn{5}{|c|}{ Site characteristic } \\
\hline Altitude (m a.s.l.) & 2,472 & 2,435 & 2,415 & 2,355 \\
\hline Slope (\%) & 30 & 15 & 15 & 15 \\
\hline \multicolumn{5}{|c|}{ Soil characteristics $(0-10 \mathrm{~cm})$} \\
\hline Soil classification (WRB, 2007) & umbric Andosol & umbric Andosol & umbric Andosol & umbric Andosol \\
\hline Sand content (\%) & 16 & 41 & 20 & 34 \\
\hline Loam content (\%) & 62 & 35 & 46 & 44 \\
\hline Clay content (\%) & 22 & 24 & 34 & 22 \\
\hline Bulk density* ( $\left.\mathrm{Mg} \mathrm{m}^{-3}\right)$ & 0.6 & 1.0 & 0.9 & 1.1 \\
\hline $\mathrm{pH}\left(\mathrm{H}_{2} \mathrm{O}\right)$ & 5.4 & 5.4 & 5.8 & 5.7 \\
\hline \multicolumn{5}{|c|}{ Tree characteristics } \\
\hline Tree density (tree ha-1) & 1,050 & 828 & 250 & 500 \\
\hline Tree basal area $\left(\mathrm{m}^{2} \mathrm{ha}^{-1}\right)$ & 27.5 & 18.4 & 17.0 & 8.8 \\
\hline Tree Species & $\begin{array}{l}\text { Q. candicans, } Q \text {. } \\
\text { obtusata, Styrax } \\
\text { raminrii, } P \text {. } \\
\text { pseudostrobus }\end{array}$ & $\begin{array}{l}\text { Q. candicans, } Q \text {. } \\
\text { obtusata, Tilia } \\
\text { mexicana, } P \text {. } \\
\text { pseudostrobus }\end{array}$ & $\begin{array}{l}\text { Q. candicans, } Q \text {. } \\
\text { obtusata, Symptocos } \\
\text { citrea, Tilia } \\
\text { mexicana }\end{array}$ & $\begin{array}{c}\text { Q. candicans, } \\
\text { Tilia mexicana, } P \text {. } \\
\text { pseudostrobus, } P \text {. } \\
\text { leiophylla }\end{array}$ \\
\hline \multicolumn{5}{|c|}{ Litter characteristics } \\
\hline Type** & Hemic & Hemic & Fibric & Hemic \\
\hline Depth (cm) & 5.0 & 5.5 & 1.0 & 4.0 \\
\hline$\%$ cover & 100 & 100 & 100 & 90 \\
\hline
\end{tabular}

The aboveground biomass was calculated using the allometric equations developed by Ayala et al. (2001) for pines and oaks of central-south Mexico:

$$
\begin{array}{ll}
\text { Oaks: } & \mathrm{AB}_{\text {(oaks) }}=\left(1.91_{*} \mathrm{DBH}^{1.782}\right) \\
\text { Pines: } & \mathrm{AB}_{\text {(pines) }}=\left(0.084_{*} \mathrm{DBH}^{2.47}\right)
\end{array}
$$

where, $\mathrm{AB}$ is aboveground biomass (for oaks and pines, respectively).

All biomass values were converted to carbon content using a factor of $0.45 \mathrm{Mg}$ carbon per $1 \mathrm{Mg}$ of dry matter (IPCC 1996). The carbon content in belowground biomass was estimated from aboveground biomass using an expansion factor of 0.26 proposed by Cairns et al. (1997).

In each site, three surface litter samples were randomly collected within the circular plot. The samples were removed from the interior of a $17 \mathrm{~cm} \mathrm{x} 17 \mathrm{~cm}$ frame. Samples were obtained in three different seasons: dry season (April), early rainy season (June), and end of rainy season (October). The material was collected and stored in plastic bags and ovendried at $60{ }^{\circ} \mathrm{C}$ for $48 \mathrm{~h}$. Samples were grounded $(0.425 \mathrm{~mm})$ and stored until chemical analyses were performed.

For litterfall sampling, three transects were established randomly at each site. In each transect, five circular nylon traps were located at $1 \mathrm{~m}$ distance between them and a height of $0.5 \mathrm{~m}$ above ground. Therefore, 15 traps were set by site giving a total area of $0.5 \mathrm{~m}^{2}$ collection. The litterfall material accumulated in each trap was collected every month during two years, starting in January 2006. The material was stored in plastic bags, oven-dried at $60{ }^{\circ} \mathrm{C}$ for four days before weighting, and afterwards grounded and stored until chemical analyses were performed.

A soil profile was opened to a depth of $1.0 \mathrm{~m}$ in each forest site. For each horizon, three samples were taken for carbon analyses and bulk density using a stainless steel core of $5 \times 5 \mathrm{~cm}^{2}$. The carbon content per unit area was calculated using the values of soil mass, bulk density, and the carbon concentration of each sample. The mean value of the three samples for each horizon was added for calculating the total soil carbon content without stone content. 
For soil nutrient dynamics, three random transects of $10 \mathrm{~m}$ were established in each site. In each transect, ten soil samples were taken with a core sampler at a distance of $1 \mathrm{~m}$ each from the top to a depth of $-10 \mathrm{~cm}$. The samples from each transect were mixed to obtain three composite samples for each site. Sampling was performed in three seasons: dry (April), early rainy (June), and rainy season (October). The samples were stored in black plastic bags at $4{ }^{\circ} \mathrm{C}$ before laboratory analyses were performed. Soil and plant samples were processed either in the laboratory of Soil Biogeochemistry at CIECO, UNAM, México and in the chemical laboratory at IRNASA, C.S.I.C., Spain.

Laboratory procedures. An aliquot for each sample of standing litter was oven-dried at $450{ }^{\circ} \mathrm{C}$ for four days and the remaining material weighted, and converted to percentage of ash in each litter sample. This value was used for ash-free correction of the dry weight mass and the resulting value converted to carbon content by multiplying its mass by its carbon concentration.

Sub-samples of plant material were grounded in a Thomas Sci. mill to pass through a 40-mesh screen $(0.425 \mathrm{~mm})$. Total carbon was determined by coulometric detection (Huffman 1977). Total nitrogen and phosphorus were determined after acid digestion. Nitrogen was determined by a macro-Kjeldahl method adapted for plant material (Bremmer 1996) and phosphorus by the molybdate colorimetric method after ascorbic acid reduction (Murphy and Riley 1962).

The composite soil samples were passed through a 2-mm sieve. A sub-sample was oven-dried at $105^{\circ} \mathrm{C}$ to constant weight for soil moisture determination by the gravimetric method. Each dry sample was grounded in an agata mortar prior to total soil nutrient analyses. Total carbon was determined by dry combustion and coulometric detection (Huffman 1977). A correction for inorganic carbon was unnecessary because the soil reaction is acid; hence, its average concentration in these soils ( $<0.02 \%)$ was considered negligible. Total nitrogen and phosphorus were determined after acid digestion with $\mathrm{H}_{2} \mathrm{SO}_{4}, \mathrm{H}_{2} \mathrm{O}_{2}$, $\mathrm{K}_{2} \mathrm{SO}_{4}$ and $\mathrm{CuSO}_{4}$ at $360^{\circ} \mathrm{C}$. Total nitrogen (Nt) was determined after acid digestion by the macro-Kjeldahl method and colorimetrically determined (Bremmer 1996). Total phosphorus was determined by the molybdate colorimetric method after ascorbic acid reduction (Murphy and Riley 1962). Inorganic nitrogen $\left(\mathrm{NH}_{4}^{+}\right.$and $\left.\mathrm{NO}_{3}^{-}\right)$was extracted from fresh sub-samples with $2 \mathrm{M} \mathrm{KCl}$, followed by filtration through a Whatman $\mathrm{N}^{\circ} 1$ paper filter (Robertson et al. 1999), and colorimetrically determined by the phenolhypochlorite method (Robertson et al. 1999).

Total dissolved nitrogen (TDN) and total dissolved phosphorus (TDP) were extracted with deionized water after shaking for $1 \mathrm{~h}$ and filtering through a Millipore 0.42 $\mu \mathrm{m}$ filter (Jones and Willett 2006); the filtrate was acid digested and colorimetrically determined as $\mathrm{NH}_{4}{ }^{+}$and total phosphorus. Dissolved organic nitrogen (DON) and dissol- ved organic phosphorus (DOP) were calculated as the difference between TDN and TDP forms and inorganic forms $\left(\mathrm{NH}_{4}{ }^{+}\right.$and DIP, respectively). Prior to acid digestion one aliquot of the filtrate was used to determine dissolved $\mathrm{NH}_{4}^{+}$ and inorganic phosphorus (as orthophosphates) in deionized water extracts. Dissolved organic carbon (DOC) was extracted from soil samples with deionized water $(1: 5 \mathrm{w} / \mathrm{v})$ after shaking for $1 \mathrm{~h}$, filtering through a $0.42-\mu \mathrm{m}$ millipore (cellulose-acetate filter) and determined in the carbon analyzer.

Microbial carbon and nitrogen concentrations were determined in field-moist samples by the chloroform fumigation-extraction method (Vance et al. 1987). Fumigated and non-fumigated samples were incubated during $24 \mathrm{~h}$ at $25^{\circ} \mathrm{C}$ and constant moisture. Microbial carbon was extracted from both fumigated and non-fumigated samples with $0.5 \mathrm{M}$ $\mathrm{K}_{2} \mathrm{SO}_{4}$, filtered through Whatman $\mathrm{N}^{\circ} 42$ filters (Brookes et al. 1985). Carbon concentration was measured in the carbon analyzer (see above). Microbial carbon was calculated by subtracting the extracted carbon in non-fumigated samples from that of fumigated samples and dividing it by a KEC value of 0.45 (Joergensen 1996). Microbial nitrogen was extracted with the same procedure used for microbial carbon, but was filtered through a Whatman $\mathrm{N}^{\circ} 1$ paper. The filtrate was acid digested and determined as total nitrogen by a macro-Kjeldahl method (Brookes et al. 1985). Microbial nitrogen was calculated in a similar way microbial carbon was, but divided by a KEN value of 0.54 (Joergensen and Muller 1996).

Potential carbon mineralization was measured in 42-day laboratory aerobic incubations; $25 \mathrm{~g}$ of soil subsamples were placed in a plastic vessel and its moistures brought to $55 \%$ of field capacity with de-ionized water. The samples were then placed in $1 \mathrm{~L}$ jars and incubated at $25{ }^{\circ} \mathrm{C}$. The jars were regularly aerated and soil moisture was adjusted every two days using a gravimetric procedure. Potential carbon mineralization was estimated as evolved $\mathrm{CO}_{2}$-carbon collected in $0.5 \mathrm{~N} \mathrm{NaOH}$ traps placed inside the jars. Carbonates were precipitated by adding $1.5 \mathrm{M}$ $\mathrm{BaCl}_{2}$ and then titrated with $0.5 \mathrm{~N} \mathrm{HCl} . \mathrm{CO}_{2}$-carbon values were corrected for soil dry weight.

All carbon forms analyzed were determined with a total carbon analyzer UIC model CM5012 (Chicago, USA), while final nitrogen and phosphorus determinations were colorimetrically done using a Bran-Luebbe Autoanalyzer 3 (Norderstedt, Germany) using the methods described above.

Calculation and statistical analyses. The average of litter mass and carbon content of the three sampling dates was used to calculate annual litter mass. Carbon and nutrient fluxes were calculated by multiplying the litterfall biomass by its nutrient concentration. Although the traps were established in the four sites, they only remained in two of them (seminatural forest and degraded forest); in the other two (forest with low degradation and burned forest) they 
were destroyed by humans or animals. The decomposition constant ( $k$ ) was estimated according Olson (1963):

$$
k=\mathrm{P} / \mathrm{L}
$$

where $\mathrm{P}$ is the annual litterfall production $\left(\mathrm{g} \mathrm{m}^{-2}\right.$ year $\left.^{-1}\right)$ and $\mathrm{L}$ is the surface litter mass $\left(\mathrm{g} \mathrm{m}^{-2}\right)$ at the rainiest month (October).

October samples represent the lowest litter mass value through the year. The $k$ value was also calculated with the contents of nitrogen and phosphorus in the annual litterfall and litter from October samples. The inverse of this constant $k$ is the mean residence time (MRT) expressed in years.

All statistical analyses were performed with Statistica 6 software (StatSoft 2000). Data were expressed on a dryweight basis unless otherwise stated. A lineal regression between soil carbon content (1.0 m depth) and tree density and aboveground biomass was performed for all the forest sites. The comparison of litter mass, nutrient contents and nutrient ratios of litterfall fluxes between seminatural forest and degraded forest in both years was analyzed with a t-Student method (Sokal and Rohlf 1995). Data of litter and soil variables were subjected to a repeated measures analysis of variance (RMANOVA) with one between-subject factor (forest plot: seminatural forest, forest with low degradation, burned forest, and degraded forest) and one within-factor (sampling date), where dates were treated as repeated measures. A Greenhouse-Geisser correction for time factors was used when data did not meet the circularity assumption of the repeated-measures analysis. When the RMANOVA indicated significant factor effects, mean comparisons were performed with LSD Fisher multiple comparison test (von Ende 1993). Data were log-transformed to meet ANOVA assumptions when required (Sokal and Rohlf 1995), though they are reported in their original scale of measurement. In all cases $P \leq 0.05$ was taken to be significant.

\section{RESULTS}

Carbon contents in the main pools. Table 2 shows biomass and carbon contents in the main ecosystem pools for the four studied forest sites. The aboveground carbon content decreased from the seminatural forest to the more perturbed site, the degraded forest. In contrast, the carbon content in the standing litter had no clear pattern in relation to the perturbation gradient: degraded forest and burned forest presented the highest and the lowest values, respectively. Soil organic carbon content showed a pattern among forest sites similar to that of aboveground biomass. Consequently, total ecosystem carbon content was the highest in seminatural forest and the lowest in degraded forest. Additionally, the soil was the main carbon pool in all study sites, comprising between 71 to $82 \%$ of the total carbon content of the overall ecosystem.
Table 2. Biomass and carbon contents of the main ecosystem pools in four forest sites in the Cuitzeo basin, Mexico. SF: seminatural forest, LF: forest with low degradation, BF: burned forest, DF: degraded forest. *Belowground carbon content was estimated by multiplying aboveground carbon content with expansion factor of 0.26 (Cairns et al. 1997). SOC: Soil organic carbon.

Biomasa y contenidos de carbono en los almacenes principales del ecosistema en los cuatro sitios en la cuenca de Cuitzeo, México. SF: bosque seminatural, LF: bosque con poca degradación, BF: bosque quemado, DF: bosque degradado. *El contenido de carbono en la biomasa subterránea fue calculado multiplicando el contenido de carbono en la biomasa aérea por 0,26 (Cairns et al. 1997). SOC: carbono orgánico del suelo.

\begin{tabular}{lcccc}
\hline \multicolumn{1}{c}{ Pools } & SF & LF & BF & DF \\
\hline \multicolumn{5}{c}{ Biomass (dry matter, $\left.\mathrm{Mg} \mathrm{ha}^{-1}\right)$} \\
\hline Aboveground & 315 & 245 & 94 & 76 \\
Litter & 22 & 18 & 10 & 24 \\
\hline \multicolumn{5}{c}{ Carbon content $\left(\mathrm{Mg} \mathrm{ha}^{-1}\right)$} \\
Aboveground & 142 & 110 & 42 & 34 \\
Litter & 9 & 7 & 4 & 10 \\
Belowground* & 37 & 29 & 11 & 9 \\
SOC (0-1 m) & 482 & 366 & 273 & 250 \\
\hline \multicolumn{1}{c}{ Total } & 670 & 512 & 330 & 303 \\
\hline
\end{tabular}

Litterfall fluxes. Both seminatural forest and degraded forest showed seasonal variations in the litterfall mass production, where the highest values were registered in spring (March and April) and the lowest during the rainy season for both years (especially September and October; figure 1). Seminatural forest presented higher annual litterfall mass production than that presented by degraded forest for both years $(P<0.001$; table 3$)$. Both sites presented a similar amount of litterfall mass for all sampling dates except for the months of March (that presented the highest litterfall mass; spring, figure 1). The monthly pattern of litterfall production was similar for both years (figure 1), but the second year showed a lower production (table 3). This pattern was associated with the amount and annual distribution of the rainfall (1,077 and $969 \mathrm{~mm}^{\text {year }}{ }^{-1}$ for 2006 and 2007, respectively).

The carbon concentrations of litterfall samples were similar for both sites and sampling dates (between 46 and 48 $\%$ in all cases). As a result, carbon fluxes were higher for seminatural forest than for degraded forest in both years ( $P<0.001$ and $P<0.01$ for the first and the second sampling year, respectively; table 3 ).

Litter decomposition rate was higher in seminatural forest than in degraded forest $\left(0.51\right.$ and 0.30 year $^{-1}$, respectively), which indicates that litter mean residence time was higher in degraded forest than in seminatural forest (3.0 and 1.8 year, respectively; table 3 ). These results suggest that a carbon flux from litter to the soil was higher in seminatural forest than in degraded forest. Similarly, nitrogen 


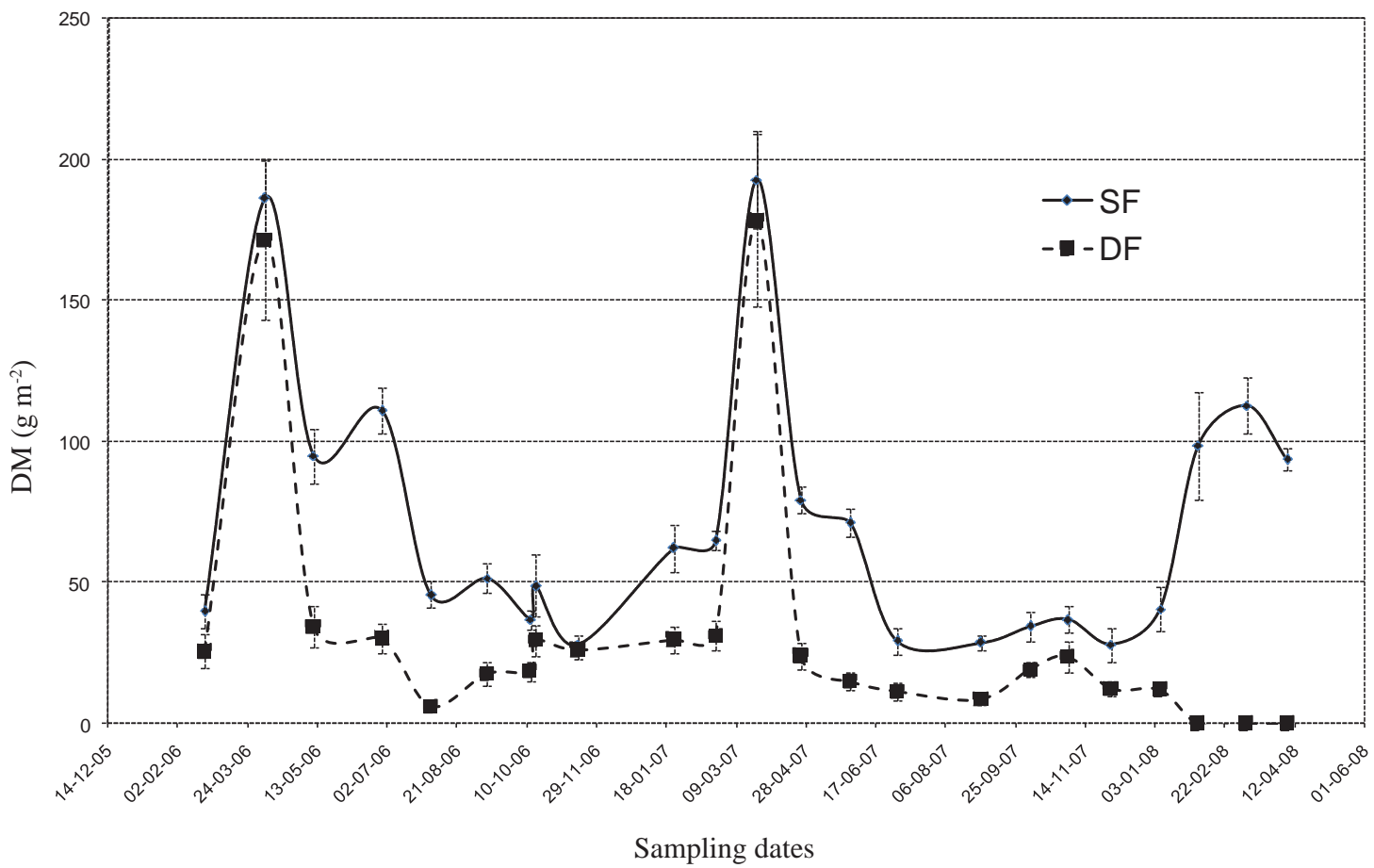

Figure 1. Average and standard errors of litterfall mass production during two years in two forest sites in the Cuitzeo basin, Mexico. SF: seminatural forest, and DF: degraded forest. The DF site had no data in the three last dates.

Promedio y error estándar de la producción de hojarasca durante dos años consecutivos en dos sitios de la cuenca de Cuitzeo, México. SF: bosque seminatural y DF: bosque degradado. El sitio DF no tiene datos en las tres últimas fechas.

and phosphorus fluxes were higher in seminatural forest than in degraded forest $(P<0.001$ and $P<0.001$, respectively), as well as the decomposition rate, which resulted in a higher MRT of both nutrients in degraded forest (table 3).

The carbon:nitrogen ratio was lower in seminatural forest than in degraded forest for the first year $(P<0.001)$, though it was similar for both sites in the second year $(P=0.17$; table 3$)$. In contrast, carbon:phosphorus and nitrogen:phoaphorus ratios were similar for both sites in all cases $(P=0.93$ and $P=0.73$, respectively; table 3$)$. These results suggest a higher litterfall quality for the decomposition in degraded forest during the first year, probably explaining its higher decomposition rate in relation to degraded forest litterfall.

Nutrient dynamics in surface litter. The amount of standing litter was statistical different among sites depending of the sampling dates $(P<0.05$; tables 4 and 5$)$. Seminatural forest presented a significantly higher amount of necromass than that presented by burned forest for April samples; nevertheless, these differences disappeared for the other two sampling dates (table 4). Seasonal dynamics were different among forest sites: burned forest presented no differences between sampling dates, in forest with low degradation April samples showed higher values than those presented by June samples, while in seminatural forest and degraded forest litter mass decreased from April to October (table 4).
The carbon contents of the standing litter presented similar patterns to those from the litter mass, which showed a significant difference among forest sites by sampling dates interaction $(P<0.01$; table 5$)$. In contrast, the nitrogen contents of the standing litter showed no significant differences for any of the factors analyzed (forest plot and sampling date; table 5). As a consequence, April samples had higher carbon:nitrogen ratios than those found in the other two sampling dates $(P<0.0001$; tables 4 and 5$)$.

The phosphorus content of the standing litter was also affected by the interaction of forest sites and sampling dates $(P<0.01$; table 5$)$. In April samples, seminatural forest and forest with low degradation showed higher litter phosphorus contents than those shown by burned forest and degraded forest in the standing litter, while these differences were not significant for the other two sampling dates (table 4). Also, April samples had higher values than those presented by the other two sampling dates in seminatural forest and forest with low degradation, while no sampling date differences were found for the other two forest sites (burned forest and degraded forest; table 4).

Similarly, the interaction of forest sites and sampling dates was significant for the nitrogen:phosphorus ratio $(P<0.05$; table 5). In April, burned forest had higher values than those found in seminatural forest and forest with low degradation, in June no differences were found among the forest sites, and degraded forest presented lower values 
Table 3. Average and standard error of litterfall production and annual litterfall fluxes of carbon, nitrogen and phosphorus in two forested sites in the Cuitzeo Basin, Mexico. SF: seminatural forest, and DF: degraded forest. MRT: mean residence time. *: means that sites were significantly different at $P<0.05$ with t-Student test. N. a.: Not applicable.

Promedio y error estándar de la producción de hojarasca y de los flujos anuales de carbono, nitrógeno y fósforo en dos sitios en la cuenca de Cuitzeo, México. SF: bosque seminatural y DF: bosque degradado. MRT: tiempo medio de residencia. *: Significa que lo sitios fueron diferentes significativamente a $P<0,05$ con la prueba de t-Student. N. a.: No aplicable.

\begin{tabular}{|c|c|c|c|c|}
\hline Years & & Year 2006-07 & & Year 2007-08 \\
\hline & & $k$ litter & MRT litter & \\
\hline Littefall production & $\mathrm{g} \mathrm{m}^{-2}$ year $^{-1}$ & year $^{-1}$ & year & $\mathrm{g} \mathrm{m}^{-2}$ year $^{-1}$ \\
\hline SF & $731 \pm 28^{*}$ & 0.51 & 1.8 & $542 \pm 16^{*}$ \\
\hline $\mathrm{DF}$ & $384 \pm 47$ & 0.30 & 3.0 & $251 \pm 49$ \\
\hline Litterfall carbon & $\mathrm{g} \mathrm{m}^{-2}$ year $^{-1}$ & & & $\mathrm{~g} \mathrm{~m}^{-2}$ year $^{-1}$ \\
\hline SF & $334 \pm 13^{*}$ & 0.52 & 1.9 & $252 \pm 7^{*}$ \\
\hline $\mathrm{DF}$ & $180 \pm 22$ & 0.38 & 2.7 & $120 \pm 24$ \\
\hline Litterfall nitrogen & $\mathrm{g} \mathrm{m}^{-2}$ year $^{-1}$ & & & $\mathrm{~g} \mathrm{~m}^{-2}$ year $^{-1}$ \\
\hline SF & $2.4 \pm 0.1^{*}$ & 0.15 & 6.8 & $3.1 \pm 0.1^{*}$ \\
\hline $\mathrm{DF}$ & $1.4 \pm 0.2$ & 0.12 & 8.2 & $1.6 \pm 0.3$ \\
\hline Litterfall phosphorus & $\mathrm{g} \mathrm{m}^{-2}$ year $^{-1}$ & & & $\mathrm{~g} \mathrm{~m}^{-2}$ year $^{-1}$ \\
\hline SF & $0.35 \pm 0.01^{*}$ & 0.32 & 3.2 & $0.33 \pm 0.02 *$ \\
\hline DF & $0.18 \pm 0.02$ & 0.14 & 7.3 & $0.15 \pm 0.03$ \\
\hline \multicolumn{5}{|l|}{ Litterfall C:N } \\
\hline SF & $129 \pm 0.3^{*}$ & N. a. & N. a. & $74 \pm 0.2$ \\
\hline $\mathrm{DF}$ & $135 \pm 0.7$ & N. a. & N. a. & $75 \pm 0.6$ \\
\hline \multicolumn{5}{|l|}{ Litterfall C:P } \\
\hline SF & $959 \pm 23$ & N. a. & N. a. & $778 \pm 39$ \\
\hline $\mathrm{DF}$ & $991 \pm 59$ & N. a. & N. a. & $784 \pm 142$ \\
\hline \multicolumn{5}{|l|}{ Litterfall N:P } \\
\hline SF & $7.4 \pm 0.04$ & N. a. & N. a. & $9.7 \pm 0.2$ \\
\hline $\mathrm{DF}$ & $7.4 \pm 0.08$ & N. a. & N. a. & $10.9 \pm 0.4$ \\
\hline
\end{tabular}

than those presented by seminatural forest and forest with low degradation in October (table 4). In seminatural forest and forest with low degradation, the April samples showed lower nitrogen:phosphorus ratios than those shown by the other two sampling dates, while these values were similar for all sampling dates in burned forest and degraded forest (table 4).

Soil nutrients dynamics. Seminatural forest and degraded forest presented the highest and the lowest soil moisture content respectively, while the other two forest sites showed intermediate values depending on the sampling date ( $P<0.001$; tables 5 and 6$)$. As expected, April samples (dry season) had the lowest values in all forest sites (table 6). Soil pH measured was only affected by sampling season $(P<0.0001$; table 5$)$, showing its lowest values in April samples (table 6).

Seminatural forest and degraded forest had the highest and the lowest values of total carbon concentration respectively $(P<0.001$; tables 5 and 6$)$. The effect of forest plot on total nitrogen concentration was different depending on the sampling season $(P<0.001$; table 5): seminatural forest showed the highest values in all dates, but forest with low degradation was higher than burned forest and degraded forest only for the April sampling (table 6). Similarly, the interaction of forest plot and sampling date also affected carbon:nitrogen ratios $(P<0.01$; table 5). Burned forest and degraded forest had higher carbon:nitrogen ratios than those found in the other forest sites in April samples, but no differences were found among forest sites in June and October (table 6). 
Table 4. Average and standard error of mass, carbon, nitrogen and phosphorus contents, and C:N and N:P ratios of standing litter in four forest sites in the Cuitzeo basin, Mexico. SF: seminatural forest, LF: forest with low degradation, BF: burned forest, DF: degraded forest. Values vertically followed by a different uppercase letter indicate that means are significantly different $(P \leq 0.05)$ among forest sites within the same sampling date; whereas different horizontally displayed lower-case letters indicate that the means are significantly different $(P \leq 0.05)$ among sampling dates within a forest plot.

Promedio y error estándar de la masa, contenidos de C, N y P y de los cocientes C:N y N:P del mantillo en los cuatro sitios en la cuenca de Cuitzeo, México. SF: bosque seminatural, LF: bosque con poca degradación, BF: bosque quemado, DF: bosque degradado. Valores seguidos verticalmente por diferente letra mayúscula indica diferencias significativas $(P \leq 0,05)$ entre parcelas forestales en la misma fecha, mientras que diferentes letras minúsculas indican que las medias son diferentes $(P \leq 0,05)$ entre fechas al interior de cada parcela.

\begin{tabular}{|c|c|c|c|c|}
\hline Dates & Dry season & Early rainy season & Rainy season & Annual means \\
\hline \multicolumn{5}{|c|}{ Litter necromass $\left(\mathrm{Mg} \mathrm{ha}^{-1}\right)$} \\
\hline SF & $4.2 \pm 0.3^{\mathrm{Aa}}$ & $1.9 \pm 0.8^{\mathrm{Ab}}$ & $1.4 \pm 0.4^{\mathrm{Ab}}$ & $2.5 \pm 0.5$ \\
\hline LF & $3.3 \pm 1.0^{\mathrm{ABa}}$ & $1.3 \pm 0.5^{\mathrm{Ab}}$ & $2.1 \pm 0.4^{\mathrm{Aab}}$ & $2.2 \pm 0.4$ \\
\hline $\mathrm{BF}$ & $1.4 \pm 0.1^{\mathrm{Ba}}$ & $0.9 \pm 0.4^{\mathrm{Aa}}$ & $1.2 \pm 0.1^{\mathrm{Aa}}$ & $1.2 \pm 0.1$ \\
\hline DF & $3.4 \pm 0.2^{\mathrm{ABa}}$ & $2.3 \pm 0.5^{\mathrm{Aab}}$ & $1.2 \pm 0.3^{\mathrm{Ab}}$ & $2.3 \pm 0.4$ \\
\hline \multicolumn{5}{|c|}{ Litter carbon content $\left(\mathrm{Mg} \mathrm{ha}^{-1}\right)$} \\
\hline SF & $1.68 \pm 0.1^{\mathrm{Aa}}$ & $0.80 \pm 0.4^{\mathrm{Ab}}$ & $0.64 \pm 0.2^{\mathrm{Ab}}$ & $1.04 \pm 0.2$ \\
\hline LF & $1.23 \pm 0.3^{\mathrm{ABa}}$ & $0.55 \pm 0.2^{\mathrm{Ab}}$ & $0.95 \pm 0.2^{\mathrm{Aab}}$ & $0.91 \pm 0.2$ \\
\hline $\mathrm{BF}$ & $0.54 \pm 0.1^{\mathrm{Ba}}$ & $0.47 \pm 0.2^{\mathrm{Aa}}$ & $0.51 \pm 0.1^{\mathrm{Aa}}$ & $0.52 \pm 0.1$ \\
\hline DF & $1.36 \pm 0.1^{\mathrm{ABa}}$ & $0.93 \pm 0.2^{\mathrm{Aab}}$ & $0.49 \pm 0.1^{\mathrm{Ab}}$ & $0.93 \pm 0.1$ \\
\hline \multicolumn{5}{|c|}{ Nitrogen content $\left(\mathrm{kg} \mathrm{ha}^{-1}\right)$} \\
\hline SF & $163 \pm 21$ & $228 \pm 82$ & $177 \pm 58$ & $189 \pm 31$ \\
\hline LF & $158 \pm 55$ & $152 \pm 54$ & $255 \pm 68$ & $188 \pm 34$ \\
\hline $\mathrm{BF}$ & $59 \pm 12$ & $92 \pm 37$ & $133 \pm 11$ & $95 \pm 16$ \\
\hline $\mathrm{DF}$ & $148 \pm 01$ & $262 \pm 70$ & $112 \pm 33$ & $174 \pm 32$ \\
\hline \multicolumn{5}{|c|}{ Phosphorus content $\left(\mathrm{kg} \mathrm{ha}^{-1}\right)$} \\
\hline SF & $108 \pm 20^{\mathrm{Aa}}$ & $14 \pm 05^{\mathrm{Ab}}$ & $11 \pm 03^{\mathrm{Ab}}$ & $45 \pm 17$ \\
\hline LF & $117 \pm 36^{\mathrm{Aa}}$ & $08 \pm 03^{\mathrm{Ab}}$ & $19 \pm 05^{\mathrm{Ab}}$ & $48 \pm 20$ \\
\hline $\mathrm{BF}$ & $27 \pm 19^{\text {Ва }}$ & $07 \pm 03^{\mathrm{Aa}}$ & $13 \pm 02^{\mathrm{Aa}}$ & $15 \pm 19$ \\
\hline DF & $31 \pm 02^{\mathrm{Ba}}$ & $19 \pm 06^{\mathrm{Aa}}$ & $13 \pm 02^{\mathrm{Aa}}$ & $21 \pm 0.9$ \\
\hline \multicolumn{5}{|c|}{$\mathrm{C}: \mathrm{N}$} \\
\hline SF & $109 \pm 25^{\mathrm{a}}$ & $33 \pm 3^{b}$ & $37 \pm 1^{\mathrm{b}}$ & $59 \pm 14$ \\
\hline LF & $82 \pm 6^{\mathrm{a}}$ & $36 \pm 2^{\mathrm{b}}$ & $38 \pm 2^{\mathrm{b}}$ & $52 \pm 8$ \\
\hline $\mathrm{BF}$ & $101 \pm 11^{\mathrm{a}}$ & $51 \pm 7^{b}$ & $39 \pm 2^{\mathrm{b}}$ & $64 \pm 10$ \\
\hline DF & $92 \pm 7^{\mathrm{a}}$ & $36 \pm 1^{\mathrm{b}}$ & $45 \pm 3^{b}$ & $58 \pm 9$ \\
\hline \multicolumn{5}{|c|}{$\mathrm{N}: \mathrm{P}$} \\
\hline SF & $1.6 \pm 0.3^{\mathrm{Bb}}$ & $15.5 \pm 0.5^{\mathrm{Aa}}$ & $15.4 \pm 1.3^{\mathrm{Aa}}$ & $11 \pm 2$ \\
\hline LF & $1.3 \pm 0.1^{\mathrm{Bb}}$ & $18.1 \pm 1.0^{\mathrm{Aa}}$ & $13.5 \pm 0.1^{\text {Аa }}$ & $11 \pm 3$ \\
\hline $\mathrm{BF}$ & $8.0 \pm 5.9^{\mathrm{Aa}}$ & $14.1 \pm 0.8^{\mathrm{Aa}}$ & $10.8 \pm 0.8^{\mathrm{ABa}}$ & $11 \pm 2$ \\
\hline DF & $4.9 \pm 0.3^{\mathrm{ABa}}$ & $13.5 \pm 0.8^{\text {Аа }}$ & $8.3 \pm 1.3^{\mathrm{Ba}}$ & $9 \pm 1$ \\
\hline
\end{tabular}


Table 5. F-ratios and significant level of the repeated measurements ANOVA for variables in four forest sites in the Cuitzeo basin, Mexico. * $=P<0.05$; ** $=P<0.01$; $* * *=P<0.001$; ns $=$ not significantly. DOC: dissolved organic carbon, DON: dissolved organic nitrogen, DOP: dissolved organic phosphorus; $\mathrm{NH}_{4}^{+}$: ammonium, $\mathrm{NO}_{3}^{-}$: nitrate, and $\mathrm{CO}_{2}-\mathrm{C}$ : potential carbon mineralization.

Valores de F y nivel de significancia del ANOVA de medidas repetidas para diferentes variables en los cuatro sitios en la cuenca de Cuitzeo, México. ${ }^{*}=P<0,05 ; * *=P<0,01 ; * * *=P<0,001$; ns $=$ no significativo. DOC: carbono orgánico disuelto, DON: nitrógeno orgánico disuelto, DOP: fósforo orgánico disuelto; $\mathrm{NH}_{4}^{+}$: amonio; $\mathrm{NO}_{3}^{-}$: nitrato, Cmic: carbono microbiano, Nmic: nitrógeno microbiano, y $\mathrm{CO}_{2}-\mathrm{C}$ : mineralización potencial de carbono.

\begin{tabular}{lll}
\hline Parameters & \multicolumn{2}{c}{ Source of variation } \\
\cline { 2 - 3 } & Between subjects & \multicolumn{2}{c}{ Within subjects } \\
\cline { 2 - 3 } Forest plot (F) & Date (D) $\quad$ FxD \\
\hline
\end{tabular}

Litter

\begin{tabular}{llll} 
Mass & $2^{\mathrm{ns}}$ & $20^{* * *}$ & $3^{*}$ \\
C content & $2^{\mathrm{ns}}$ & $19^{* * *}$ & $4^{* *}$ \\
$\mathrm{~N}$ content & $2^{\mathrm{ns}}$ & $2^{\mathrm{ns}}$ & $2^{\mathrm{ns}}$ \\
$\mathrm{P}$ content & $4^{*}$ & $25^{* * *}$ & $4^{* * *}$ \\
$\mathrm{C}: \mathrm{N}$ & $1^{\mathrm{ns}}$ & $62^{* * *}$ & $1^{\mathrm{ns}}$ \\
$\mathrm{N}: \mathrm{P}$ & $1^{\mathrm{ns}}$ & $34^{* * *}$ & $3^{*}$ \\
\hline
\end{tabular}

Soil

\begin{tabular}{llll} 
Humidity & $59^{* * *}$ & $462^{* * *}$ & $7^{* * *}$ \\
$\mathrm{pH}$ & $1^{\mathrm{ns}}$ & $51^{* * *}$ & $1^{\mathrm{ns}}$ \\
Total C & $18^{* * *}$ & $1^{\mathrm{ns}}$ & $1^{\mathrm{ns}}$ \\
Total N & $42^{* * *}$ & $2^{\mathrm{ns}}$ & $6^{* * *}$ \\
$\mathrm{C}: \mathrm{N}$ & $1^{\mathrm{ns}}$ & $1^{\mathrm{ns}}$ & $3^{*}$ \\
$\mathrm{DOC}$ & $1^{\mathrm{ns}}$ & $5^{*}$ & $2^{\mathrm{ns}}$ \\
$\mathrm{DON}$ & $1^{\mathrm{ns}}$ & $15^{* * *}$ & $1^{\mathrm{ns}}$ \\
$\mathrm{NH}_{4}^{+}$ & $41^{* * *}$ & $37^{* * *}$ & $8^{* * *}$ \\
$\mathrm{NO}_{3}^{-}$ & $1^{\mathrm{ns}}$ & $3^{\mathrm{ns}}$ & $1^{\mathrm{ns}}$ \\
$\mathrm{Microbial} \mathrm{C}^{-}$ & $7^{* *}$ & $6^{*}$ & $7^{* *}$ \\
$\mathrm{Microbial} \mathrm{N}$ & $15^{* * *}$ & $5^{*}$ & $1^{\mathrm{ns}}$ \\
$\mathrm{CO}_{2}-\mathrm{C}$ & $280^{* * *}$ & $763^{* * *}$ & $82^{* * *}$ \\
\hline
\end{tabular}

Table 6. Average and standard error of soil moisture, $\mathrm{pH}$, soil concentrations of carbon, nitrogen, and phosphorus, and C:N ratios from the top $-10 \mathrm{~cm}$ soil depth in four forest sites in the Cuitzeo basin, Mexico. SF: seminatural forest, LF: forest with low degradation, BF: burned forest, DF: degraded forest. Values vertically followed by a different uppercase letter indicate that means are significantly different $(P \leq 0.05)$ among forest sites within the same sampling date; whereas different horizontally displayed lowercase letters indicate that the means are significantly different $(P \leq 0.05)$ among sampling dates within a forest plot.

Promedio y error estándar de la humedad del suelo, pH, concentraciones de carbono, nitronen y phosphorus, y los cocientes C: $\mathrm{N}$ de los primero $10 \mathrm{~cm}$ del suelo en los cuatro sitios en la cuenca de Cuitzeo, México. SF: bosque seminatural, LF: bosque con poca degradación, BF: bosque quemado, DF: bosque degradado. Valores seguidos verticalmente por diferente letra mayúscula indica diferencias significativas $(P \leq 0,05)$ entre parcelas forestales en la misma fecha, mientras que diferentes letras minúsculas indican que las medias son diferentes $(P \leq 0,05)$ entre fechas al interior de cada parcela.

Dates Dry season Early rainy season Rainy season
Soil moisture (\%)

$\begin{array}{llll}\text { SF } & 24 \pm 1.1^{\mathrm{Ab}} & 47 \pm 1.6^{\mathrm{Aa}} & 49 \pm 1.8^{\mathrm{Aa}} \\ \text { LF } & 24 \pm 1.6^{\mathrm{Ab}} & 40 \pm 0.4^{\mathrm{Aa}} & 38 \pm 1.8^{\mathrm{Ba}} \\ \mathrm{BF} & 18 \pm 0.3^{\mathrm{ABc}} & 39 \pm 0.9^{\mathrm{ABa}} & 33 \pm 1.2^{\mathrm{Bb}} \\ \text { DF } & 15 \pm 0.4^{\mathrm{Bb}} & 32 \pm 0.4^{\mathrm{Ba}} & 31 \pm 0.4^{\mathrm{Ba}}\end{array}$

\begin{tabular}{llll}
\hline & \multicolumn{3}{c}{ Soil pH } \\
SF & $5.4 \pm 0.2^{\mathrm{b}}$ & $6.0 \pm 0.1^{\mathrm{a}}$ & $6.0 \pm 0.2^{\mathrm{a}}$ \\
$\mathrm{LF}$ & $5.0 \pm 0.2^{\mathrm{b}}$ & $5.8 \pm 0.1^{\mathrm{a}}$ & $5.8 \pm 0.1^{\mathrm{a}}$ \\
$\mathrm{BF}$ & $5.1 \pm 0.1^{\mathrm{b}}$ & $6.2 \pm 0.3^{\mathrm{a}}$ & $5.9 \pm 0.2^{\mathrm{a}}$ \\
$\mathrm{DF}$ & $5.1 \pm 0.1^{\mathrm{b}}$ & $5.9 \pm 0.1^{\mathrm{a}}$ & $6.0 \pm 0.1^{\mathrm{a}}$
\end{tabular}

Soil organic carbon $\left(\mathrm{g} \mathrm{kg}^{-1}\right)$

\begin{tabular}{|c|c|c|c|}
\hline SF & $120 \pm 16^{\mathrm{A}}$ & $126 \pm 19^{\mathrm{A}}$ & $142 \pm 8^{\mathrm{A}}$ \\
\hline LF & $89 \pm 11^{\mathrm{B}}$ & $90 \pm 8^{\mathrm{B}}$ & $89 \pm 7^{\mathrm{B}}$ \\
\hline $\mathrm{BF}$ & $57 \pm 4 \mathrm{~B}^{\mathrm{C}}$ & $72 \pm 6^{\mathrm{BC}}$ & $58 \pm 11^{\mathrm{BC}}$ \\
\hline DF & $50 \pm 5^{\mathrm{C}}$ & $42 \pm 9^{C}$ & $50 \pm 5^{C}$ \\
\hline \multicolumn{4}{|c|}{ Soil total nitrogen $\left(\mathrm{g} \mathrm{kg}^{-1}\right)$} \\
\hline SF & $8.3 \pm 0.6^{\mathrm{A}}$ & $6.4 \pm 0.5^{\mathrm{A}}$ & $7.0 \pm 0.4^{\mathrm{A}}$ \\
\hline LF & $6.1 \pm 0.7^{\mathrm{A}}$ & $4.6 \pm 0.3^{\mathrm{AB}}$ & $4.6 \pm 0.1^{\mathrm{AB}}$ \\
\hline $\mathrm{BF}$ & $2.6 \pm 0.2^{\mathrm{B}}$ & $4.2 \pm 0.5^{\mathrm{B}}$ & $3.1 \pm 0.3^{\mathrm{B}}$ \\
\hline DF & $2.6 \pm 0.6^{\mathrm{B}}$ & $3.2 \pm 0.2^{\mathrm{B}}$ & $3.0 \pm 0.2^{\mathrm{B}}$ \\
\hline
\end{tabular}

\begin{tabular}{|c|c|c|c|}
\hline \multicolumn{4}{|c|}{ Soil C:N } \\
\hline SF & $14 \pm 0.9^{\mathrm{Ba}}$ & $19 \pm 1.8^{\mathrm{Aa}}$ & $20 \pm 1.2^{\text {Аа }}$ \\
\hline LF & $14 \pm 0.4^{\mathrm{Ba}}$ & $19 \pm 0.8^{\mathrm{Aa}}$ & $19 \pm 1.6^{\mathrm{Aa}}$ \\
\hline $\mathrm{BF}$ & $22 \pm 1.9^{\mathrm{Aa}}$ & $17 \pm 0.5^{\mathrm{Aa}}$ & $18 \pm 1.8^{\text {Аа }}$ \\
\hline $\mathrm{DF}$ & $21 \pm 5.1^{\text {Аа }}$ & $13 \pm 2.3^{\mathrm{Ab}}$ & $17 \pm 2.3^{\text {Aab }}$ \\
\hline
\end{tabular}


The concentrations of dissolved organic carbon (DOC) and nitrogen (DON) were only affected by sampling date $(P<0.02$ and $P<0.0001$, respectively). For both variables, April samples presented higher concentrations than those presented by the samples collected during the rainy season (June and October, table 7).

The ammonium concentration was affected by the interaction between forest management and sampling date ( $P$ $<0.0005$; table 5), where seminatural forest and degraded forest had the highest and the lowest values for June and October (table 7). Similarly, April samples had the lowest ammonium concentration, but there were no differences among sampling dates in degraded forest (table 7). In contrast, nitrate concentrations were not affected by any of the factors analyzed (table 5). Their values were very low.

The forest sites had similar microbial carbon concentrations in April samples, while seminatural forest showed the highest values for October sampling (tables 5 and 7). The less perturbed forest sites (seminatural forest and forest with low degradation) had higher microbial nitrogen than that presented by the more perturbed forest sites in all sampling dates (burned forest and degraded forest; $P<0.001$, tables 5 and 7). Likewise, October samples presented higher microbial nitrogen concentrations than those presented by April samples (46 and $37 \mu \mathrm{g} \mathrm{g}^{-1}$, respectively; $P<0.05$ ).

The effect of forest sites on potential carbon mineralization was different for samplings conducted in April and October $(P<0.0001$; table 5). In April, seminatural forest presented a higher potential carbon mineralization than that presented by the other three forest sites, while in October the potential carbon mineralization was the highest in seminatural forest and the lowest in burned forest (figure 2). October samples presented a higher potential carbon mineralization than that presented by April samples, independently of the forest plot (figure 2). These results suggest that the soil conditions in SF promote a higher microbial activity when compared with the other forest sites.

\section{DISCUSSION}

The carbon content in the aboveground biomass of the seminatural forest was in the range of that reported previously for oak-pine forests in central Mexico (Michoacán, 65 to $154 \mathrm{Mg} \mathrm{ha}^{-1}$; Ordoñez et al. 2008) and in the South of Mexico (Chiapas, 77 to $168 \mathrm{Mg} \mathrm{ha}^{-1}$; de Jong et al. 1999), though higher than that reported for oak-pine forests in Northwestern Mexico (65 Mg ha' ${ }^{-1}$; Navar 2009), and above the typical range of temperate forest biomass carbon (60 to $130 \mathrm{Mg} \mathrm{ha}^{-1}$; Lal 2005). Only forest ecosystems in areas with higher amount of rainfall have higher aboveground biomass carbon content than that found in seminatural forest; for example, the evergreen cloud forest in Chiapas (189 $\mathrm{Mg} \mathrm{ha}^{-1}$; de Jong et al. 1999), the tropical floodplain of the Pacific Mexican Coast (180 $\mathrm{Mg} \mathrm{ha}^{-1}$; Jaramillo et al. 2003), the tropical wet forest in the Mexican plain of the Gulf of Mexico (195 Mg ha-1; Hughes et al. 1999) and in the Lancandonian forest in the South of Mexico (233 $\mathrm{Mg} \mathrm{ha}^{-1}$; de Jong et al. 2000).

Similarly, SOC content in seminatural forest was higher than that reported for Andosols in Mexico (355 to $408 \mathrm{Mg} \mathrm{ha}^{-1}$ of carbon; Etchevers et al. 2006), and higher than the average reported for temperate ecosystems in Mexico (132 $\mathrm{Mg} \mathrm{ha}^{-1}$; Balbotín et al. 2009). This value is higher than that reported for wet ecosystems in Mexico:

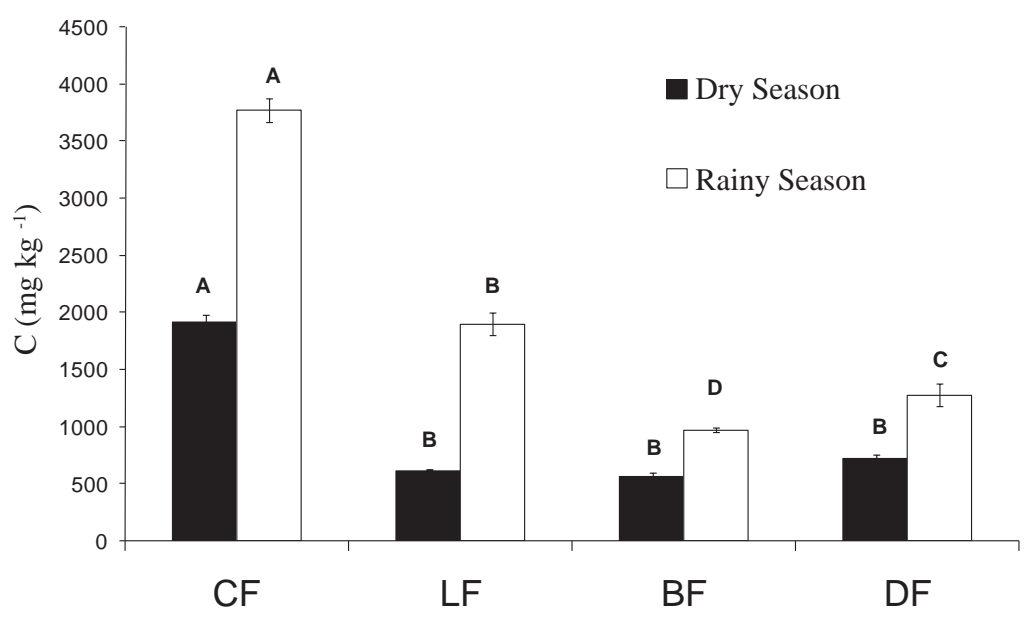

Figure 2. Means and standard errors of potential carbon mineralization $\left(\mathrm{CO}_{2}-\mathrm{C}\right)$ after 42-days incubation in four forest sites in the Cuitzeo basin, Mexico. SF: seminatural forest, LF: forest with low degradation, BF: burned forest, DF: degraded forest. Values followed by a different uppercase letter indicate that means are significantly different $(P \leq 0.05)$ among forest plots within the same sampling date.

Promedio y error estándar de la mineralización potencial de carbono $\left(\mathrm{CO}_{2}\right.$-C) después de 42 días de incubación en los cuatro sitios en la cuenca de Cuitzeo, México. SF: bosque seminatural, LF: bosque con poca degradación, BF: bosque quemado, DF: bosque degradado. Valores seguido por diferente letras mayúsculas significa que las media son diferentes $(P \leq 0,05)$ entre parcelas forestales en la misma fecha de muestreo. 
Table 7. Average and standard error of different soil nutrient concentrations from the top $10 \mathrm{~cm}$ depth in four forest sites in the Cuitzeo basin, Mexico. SF: seminatural forest, LF: forest with low degradation, BF: burned forest, DF: degraded forest. DOC: dissolved organic carbon, DON: dissolved organic nitrogen, $\mathrm{NH}_{4}^{+}$: ammonium. Values vertically followed by a different uppercase letter indicate that means are significantly different $(P \leq 0.05)$ among forest sites within the same sampling date; whereas different horizontally displayed lowercase letters indicate that the means are significantly different $(P \leq 0.05)$ among sampling dates within a forest plot.

Promedio y error estándar de la concentraciones de diferentes nutrientes del suelo de los primero $10 \mathrm{~cm}$ del suelo en los cuatro sitios en la cuenca de Cuitzeo, México. SF: bosque seminatural, LF: bosque con poca degradación, BF: bosque quemado, DF: bosque degradado. Valores seguidos verticalmente por diferente letra mayúscula indica diferencias significativas $(P \leq 0,05)$ entre parcelas forestales en la misma fecha, mientras que diferentes letras minúsculas indican que las medias son diferentes $(P \leq 0,05)$ entre fechas al interior de cada parcela.

\begin{tabular}{lccc}
\hline Dates & Dry season & Early rainy season & Rainy season \\
\hline & \multicolumn{2}{c}{ DOC $\left(\mathrm{mg} \mathrm{kg}^{-1}\right)$} \\
SF & $50 \pm 13^{\mathrm{a}}$ & $34 \pm 5^{\mathrm{b}}$ & $42 \pm 8^{\mathrm{a}}$ \\
$\mathrm{LF}$ & $47 \pm 13^{\mathrm{a}}$ & $40 \pm 1^{\mathrm{b}}$ & $50 \pm 4^{\mathrm{a}}$ \\
$\mathrm{BF}$ & $65 \pm 13^{\mathrm{a}}$ & $41 \pm 1^{\mathrm{b}}$ & $51 \pm 2^{\mathrm{a}}$ \\
DF & $48 \pm 3^{\mathrm{a}}$ & $35 \pm 6^{\mathrm{b}}$ & $59 \pm 1^{\mathrm{a}}$ \\
\hline
\end{tabular}

\section{$\mathrm{DON}\left(\mathrm{mg} \mathrm{kg}^{-1}\right)$}

\begin{tabular}{llrl} 
SF & $7.1 \pm 0.8^{\mathrm{a}}$ & $3.9 \pm 0.3^{\mathrm{b}}$ & $2.4 \pm 0.7^{\mathrm{b}}$ \\
$\mathrm{LF}$ & $6.2 \pm 0.8^{\mathrm{a}}$ & $3.4 \pm 0.1^{\mathrm{b}}$ & $3.6 \pm 0.3^{\mathrm{b}}$ \\
$\mathrm{BF}$ & $8.4 \pm 1.1^{\mathrm{a}}$ & $3.4 \pm 0.1^{\mathrm{b}}$ & $3.3 \pm 0.8^{\mathrm{b}}$ \\
$\mathrm{DF}$ & $6.5 \pm 0.4^{\mathrm{a}}$ & $4.1 \pm 0.8^{\mathrm{b}}$ & $3.4 \pm 1.3^{\mathrm{b}}$ \\
\hline & $\mathrm{NH}_{4}^{+}-\mathrm{N}\left(\mathrm{mg} \mathrm{kg}^{-1}\right)$ & \\
$\mathrm{SF}$ & $18 \pm 2^{\mathrm{Ac}}$ & $62 \pm 2^{\mathrm{Ab}}$ & $146 \pm 10^{\mathrm{Aa}}$ \\
$\mathrm{LF}$ & $36 \pm 15^{\mathrm{Ab}}$ & $48 \pm 18^{\mathrm{Ab}}$ & $102 \pm 9^{\mathrm{Ba}}$ \\
$\mathrm{BF}$ & $11 \pm 6^{\mathrm{Ab}}$ & $51 \pm 7^{\mathrm{Aa}}$ & $40 \pm 9^{\mathrm{Ca}}$ \\
DF & $10 \pm 1^{\mathrm{Aa}}$ & $29 \pm 4^{\mathrm{Ba}}$ & $32 \pm 3^{\mathrm{Ca}}$ \\
\hline
\end{tabular}

Microbial carbon ( $\left.\mathrm{mg} \mathrm{kg}^{-1}\right)$

\begin{tabular}{lllc} 
SF & $848 \pm 33^{\text {Аa }}$ & n.d. & $1161 \pm 32^{\mathrm{Ab}}$ \\
LF & $756 \pm 40^{\text {Аа }}$ & n.d. & $510 \pm 43^{\mathrm{Ba}}$ \\
BF & $805 \pm 44^{\text {Аа }}$ & n.d. & $564 \pm 6^{\mathrm{Ba}}$ \\
DF & $742 \pm 2^{\text {Аа }}$ & n.d. & $389 \pm 20^{\mathrm{Bb}}$ \\
\hline
\end{tabular}

Microbial nitrogen $\left(\mathrm{mg} \mathrm{kg}^{-1}\right)$

\begin{tabular}{llll} 
SF & $60 \pm 7$ & n.d. & $82 \pm 3$ \\
LF & $52 \pm 7$ & n.d. & $47 \pm 2$ \\
BF & $16 \pm 4$ & n.d. & $28 \pm 8$ \\
DF & $18 \pm 7$ & n.d. & $29 \pm 8$ \\
\hline
\end{tabular}

169 and $163 \mathrm{Mg} \mathrm{ha}^{-1}$ for tropical wet and temperate wet ecosystems, respectively (Balbotín et al. 2009).

The results of the present research suggest that the fragments of conserved forest represent an important reservoir of carbon among temperate forest ecosystems in Mexico. Thus, the relationship between aboveground biomass and SOC was expressed as a positive linear regression between SOC concentration and tree density and SOC and aboveground biomass $\left(\mathrm{R}^{2}=0.67\right.$ and $\mathrm{R}^{2}=0.60$, respectively). Unfortunately, remnant forest fragments in the Cuitzeo basin are under strong degradation pressure, mainly by illegal timber extraction for fuel wood and charcoal production associated with Morelia city (Ghilardi et al. 2009, Aguilar et al. 2012). For example, the ecosystem carbon pools in the degraded forest site were $55 \%$ lower than those of seminatural forest, and the aboveground carbon content was reduced $76 \%$ because tree density and biomass were strongly depleted by timber extraction (table 1). Correspondingly, SOC content up to $1 \mathrm{~m}$ depth in degraded forest also decreased by $52 \%$. The reduction of tree density (and therefore of aboveground biomass) depleted the production of litter and roots, resulting in a reduction of SOC inputs, which explained the positive correlation between SOC with tree density and with aboveground biomass. Similarly, litterfall production was higher and litter decomposition was faster in seminatural forest than in degraded forest; a similar result was found by Aceñolaza and Gallardo (1999) in the 'Yungas' forest, NW Argentina. These results suggest that SOC input was greater in seminatural forest than in degraded forest.

The reduction of SOC after forest harvesting was reported in several studies (Lal 2005) associated with an extraction of woody vegetation, decreasing of litter production and increasing decomposition of organic matter and soil erosion (Covington 1981, Johnson 1992, Aceñolaza and Gallardo 1999, Lal 2005). For example, carbon pools reduction was observed by reducing rotation harvesting (Johnson 1992, Evans 1996, Fox 2000, Lal 2005).

Seminatural forest and degraded forest had similar litter necromass although their annual litter production was two times higher than in degraded forest, suggesting a lower litter decomposition rate in degraded forest with higher surface litter temperature (Covadela et al. 2209). Several studies reported a reduction in the decomposition rate of surface litter when soil moisture content and biotic activity decreased after clear cutting (Lal 2005, Blanco et al. 2011); although, the results found are not consistent with other studies that report the increment of soil temperature with thinning intensity, promoting litter decomposition in temperate forests (Piene et al. 1978, Jandl et al. 2007, NegreteYankelevich et al. 2007). However, litter decomposition could be reduced by soil humidity depletion and changes in both litter chemical quality and composition of microbial communities (Blanco et al. 2011). Several studies reported a reduction in the decomposition rate of surface litter when soil moisture content and biotic activity decreased af- 
ter clear cutting (Aceñolaza and Gallardo 1999, Lal 2005, Blanco et al. 2011). In our study, seminatural forest had higher soil moisture than that presented by the degraded forest site for soil samples collected during the rainy season.

Another factor that can explain the surface litter accumulation in degraded forest is the reduction in the chemical quality of litter as expressed in the carbon:nitrogen ratio, which constrains microbial activity (Anderson and Domsch 1990, Blanco et al. 2011). The carbon:nitrogen ratio of litterfall was higher in degraded forest than in seminatural forest. The nitrogen and phosphorus reabsorption efficiency capacity increased in perturbed oak forest in NW Spain (Covelo et al. 2008). These increments are a result of the depletion of soil nutrient availability in the degraded plantation (Merino et al. 1998), reducing the nutrient fluxes from the vegetation to the soil. The main consequence of our results is a decrease of litter quality by an increasing carbon:nitrogen ratio, which constraints the decomposition of surface litter. For example in our study, the more degraded forest sites (burned forest and degraded forest) presented lower nitrogen and phosphorus contents in the surface litter than those found in the more conserved forest plot (seminatural forest and forest with low degradation). The phosphorus content of surface litter decreased dramatically from dry to rainy months in the less degraded forest sites (seminatural forest and forest with low degradation). These results suggest a higher phosphorus mineralization in the seminatural forest plot than in the degraded forest plot. Phosphorus release from surface litter could promote microbial activity and therefore soil fertility, which can be critical in these soils with Andic properties that are characterized by their low soil phosphorus availability (Iñiguez and Val 1984) as it is well known.

SOC and nitrogen concentrations of the top $10 \mathrm{~cm}$ soil depth were $60 \%$ lower in the degraded forest plot than in the seminatural forest plot. These results suggest that forest degradation decreased the amount of carbon and nitrogen accumulation within the soil, mainly by the reduction of organic matter inputs to the soil. Additionally, extractable soil ammonium and microbial forms of carbon and nitrogen were lower in the degraded forest plot than in the seminatural forest plot. These results suggest that the available nutrient forms are also affected by forest degradation, explained by a reduction of renewal of soil organic matter as mentioned before.

Finally, seminatural forest had the highest potential carbon mineralization among forest sites (table 7). Likewise, Covadela et al. (2009) reported that seminatural forest had higher maximum soil respiration under field conditions than did the degraded forest. These results may be a consequence of the reduction of SOC and nutrient availability, which constrain microbial activity (Anderson and Domsch 1990). Unfortunately, the forest degradation is very common in remaining forest fragments of Latin America, particularly in Mexico, mainly because of demographic growth. Hence the problem here exposed is of great relevance in Latin-America and other World zones.

\section{CONCLUSIONS}

Results of the present study suggest that forest degradation by wood extraction is depleting ecosystem carbon pools and reducing soil nutrient availability, which affects carbon sequestration capacity by constraining plant productivity. The depletion of soil nutrient availability under the degraded forest site decreased nutrient recycling limiting forest production and functions (as degradation of the standing litter). As a consequence, fertilization is required to increase forest productivity. Unfortunately, this forest degradation conditions is very common in remaining forest fragments of Latin America, particularly in Mexico.

\section{ACKNOWLEDGMENTS}

We are grateful to two anonymous reviewers for useful suggestion. This study was funded by the European Union for the support of the REVOLSO Project (INCO Program, ICA4-CT-2001-10052), the UNAM (SDEI-PTID-02), and the DESIRE (UE6, Integrated project, Contract $N^{\circ} 037046$ ). First author thanks to UNAM and Spanish CSIC for the fellowship during his academic stay in IRNASa, Spain.

\section{REFERENCES}

Aceñolaza PG, JF Gallardo. 1999. Leaf decomposition and nutrient release in Montane forest of Northwestern Argentina. Journal of Tropical Science 11: 619-630.

Aguilar R, A Ghilardi, E Vega, M Skutsch, K Oyama. 2012. Sprouting productivity and allometric relationship of two oak species managed for traditional charcoal making in Central Mexico. Biomass and Bioenergy 36: 192-207.

Anderson TH, KH Domsch. 1990. Application of eco-physiological quotients ( $q \mathrm{CO} 2$ and $q \mathrm{D}$ ) on microbial biomass from soils of different cropping histories. Soil Biology and Biochemistry 22: 251-255.

Ayala L, B de Jong, M Ramírez. 2001. Ecuaciones para estimar biomasa en la Meseta Central de Chiápas. Revista Chapingo, Serie Ciencias Forestales y del Ambiente 7: 153-158.

Balbontín C, CO Cruz, F Paz, JD Etchevers. 2009. Soil carbon sequestration in different ecoregions of Mexico. In Lal R, RF Follet eds. Madison WI, USA. Soil Carbon sequestration and the greenhose effect. 2nd. Soil Science Society of America Special publication 57. p. 71-96.

Blanco JA, JB Imbert, FJ Castillo. 2011. Thinning affects Pinus sylvestri needle decomposition rates and chemistry differently depending on site conditions. Biogeochemistry 106: 397-414.

Bremmer JM. 1996. Nitrogen-Total. In Spark DL, AL Page, ME Summer, MA Tabatabai, PA Helmke PA eds. Methods of Soil Analyses Part 3: Chemical Analyses. Madison, WI., USA. Soil Science Society of America. p. 1085-1121

Brookes P, A Landman, G Pruden, D Jenkinson. 1985. Chloroform fumigation and the release of soil nitrogen: a rapid direct extraction method to measure microbial biomass nitrogen in soil. Soil Biology and Biochemistry 17: 837-842.

Cairns MA, S Brown, EH Elmer, GA Baumgardner. 1997. Root biomass allocation in the World's upland forest. Oecologia 
111: 1-11.

Comisión Nacional Forestal (CONAFOR, MX). 2004. Inventario Nacional Forestal y de suelos. Manual y procedimientos para el muestreo de campo. Mexico, Mexico DF. Secretaría de Medio Ambiente y Recursos Naturales. 140 p.

Covadela S, C Prat, F García-Oliva, JD Etchevers, JF Gallardo, F Paz. 2009. Flujos de $\mathrm{CO}_{2}$ edáfico en un transecto de bosques de pino-encino afectados por actividad antrópica en la microcuenca de Atécuaro (Michoacán, Méjico). In Campo J, ME Conti eds. Emisiones de gases con efecto invernadero en ecosistemas Iberoamericanos. Salamanca, España. Sociedad Iberoamericana de Física y Química Ambiental. p. 123-153.

Covelo F, J Durán, A Gallardo. 2008. Leaf resorption effciency and proficiency in a Quercus robur population following harvest. Forest Ecology and Management 255: 2264-2271.

Covington WW. 1981. Changes in forest floor organic matter and nutrient content following clear cutting in northern hardwoods. Ecology 62: 41-48.

de Jong BHJ, MA Cairns, PK Haggerty, N Ramírez-Marcial, S Ochoa-Gaona, J Mendoza-Vega, M González-Espinosa, I March-Mifsut. 1999. Land-use change and carbon flux between 1970s and 1990s in the central highlands of Chiapas, México. Environmental Management 23: 373-1285.

de Jong BHJ, S Ochoa-Gaona, MA Castillo-Santiago, N Ramírez-Marcial, MA Cairns MA. 2000. Carbon flux and patterns of land-use/land-cover change in the Selva Lacandona, Mexico. Ambio 29: 504-511.

Evans J. 1996. The sustainability of wood production from plantations: evidence over three successive rotations in the Usutu Forest, Swaziland. Commonwealth Forest Review 75: 234-239.

Etchevers J, O. Masera, C Balbontín, D Gómez, A Monterroso, R Martínez, M Acosta, M Martínez, C Ortiz C. 2006. Soil carbon sequestration in Mexico and Central America (Biome A). In Lal R, CC Cerri, M Bernoux, JD Etchevers, E Cerri eds. Carbon sequestration in soils of Latin America. New York, USA. Food Product Press and the Harworth Press. p. 119-146.

Fox TR. 2000. Sustained productivity in intensively managed plantations. Forest Ecology and Management 138: 187202.

García-Oliva F, O Masera. 2004. Assessment and measurement issues related to soil carbon sequestration in Land-Use, Land-Use Change, and Forestry (LULUCF) Projects under the Kyoto Protocol. Climate Change 65: 347-364.

Ghilardi A, G Guerrero, O Masera. 2009. A GIS-based methodology for highlighting fuelwood supply/demand imbalances at the local level: A case study for Central Mexico. Biomass Bioenergy 33: 957-972.

Glaser B, J Lehmann, W Zech. 2002. Ameliorating physical and chemical properties of highly weathered soils in the tropics with charcoal—a review. Biology and Fertility of Soils 35: 219-230.

González-Espinosa M, P Quintana-Ascencio, N Ramírez-Marcial, P Gaytán-Guzmán. 1991. Secondary succession in disturbed Pinus-Quercus forests in the highlands of Chiapas, Mexico. Journal of Vegetation Science 2: 351-360.

Guo LB, RM Gifford RM. 2002. Soil carbon stocks and land use changes: a meta analysis. Global Change Biology 8: 345-360.
Huffman EWD. 1977. Performance of a new carbon dioxide coulometer. Microchemical Journal 22: 567-573.

Hughes RF, JB Kauffman, VJ Jaramillo. 1999. Biomass, carbon, and nutrient dynamics of secondary forests in a humid tropical region of México. Ecology 80: 1892-1907.

IPCC (Intergovernmental Panel on Climate Change, CH). 1996. IPCC Guidelines for National Greenhouse Gas Inventories. Chapter 5. Land-use change and forestry. Guidelines for National Greenhouse Gas Inventories: Reference Manual. Institute for Global Environmental Strategies, London, UK.

IEA (International Energy Agency, FR). 2000. Energy and poverty. In International Energy Agency ed. World energy outlook. Paris, France.

Instituto Nacional de Ecología (INE). 2009. México. Cuarta comunicación nacional ante la Convención Marco de las Naciones Unidas sobre el Cambio Climático. SEMARNAT, México city, México.

Instituto Nacional de Estadística, Geografía e Informática (INEGI). 2010. Censo de Población y Vivienda. INEGI, México City, México. <http://www3.inegi.org.mx/sistemas/TabuladosBasicos/tabulados/CPV2010/Ampliado/14_12A_ESTATAL.PDF>

Iñiguez J, RM Val. 1984. Evaluation of phosphorus sorption by an allophanic soil. Geoderma 33: 119-134.

IUSSS Working Group WRB. 2007. World Reference Base for Soil Resources 2006, first update 2007. World Soil Resources Reports No. 103. FAO, Rome

Jandl R, M Linder, L Vesterdal, B Bauwens, R Baritz, F Hagerdorn, DW Johnson, K Minkkinen, A Byrne. 2007. How strong can forest management influence soil carbon sequestration?. Geoderma 137: 253-268.

Jaramillo VJ, JB Kauffman, L Rentería-Rodríguez, DL Cummings, LJ Ellingson. 2003. Biomass, carbon, and nitrogen pools in Mexican tropical dry forest landscapes. Ecosystems 6: 609-629.

Joergensen RG. 1996. The fumigation-extraction method to estimate soil microbial biomass: calibration of the $k_{\mathrm{EC}}$ value. Soil Biology and Biochemistry 28: 25-31.

Joergensen RG, T Mueller. 1996. The fumigation-extraction method to estimate soil microbial biomass: calibration of the $k_{\mathrm{EN}}$ value. Soil Biology and Biochemistry 28: 33-37.

Johnson DW. 1992. Effects of forest management on soil carbon storage. Water Air Soil Pollution 64: 83-120.

Johnson DW, PS Curtis. 2001. Effect of forest management on soil C and N storage: meta analysis. Forest Ecology and Management 140: 227-238.

Jones DL, VB Willett. 2006. Experimental evaluation of methods to quantify dissolved organic nitrogen (DON) and dissolved organic carbon (DOC) in soil. Soil Biology and Biochemistry 38: 991-999.

Lal R. 2005. Forest soils and carbon sequestration. Forest Ecology and Management 220: 242-258.

López E, G Bocco, M Mendoza, A Velázquez, JR Aguirre-Rivera. 2006. Peasant emigration and land-use change at the watershed level: A GIS-based approach in Central Mexico. Agriculture Systems 90: 62-78.

Merino A, J Edeso, M Gonzalez, P Marauri. 1998. Soil properties in a hilly area following different harvesting management practices. Forest Ecology and Management 103: 235-246.

Murphy J, JP Riley. 1962. A modified single solution method for the determination of phosphate in natural waters. Anal Che- 
mical Acta 27: 31-36.

Murty D, MUF Kirschbaum, RE McMurtrie, H McGilvray. 2002. Does conversion of forest to agricultural land change soil carbon and nitrogen? A review of the literature. Global Change Biology 8: 105-123.

Navar J. 2009. Allometric equations for tree species and carbon stocks for forest of Northwestern Mexico. Forest Ecology and Management 257: 427-434.

Negrete-Yankelevich S, C Fragoso, AC Newton, OW Heal. 2007. Successional changes in soil, litter and macroinvertebrates parameters following selective logging in a Mexican Cloud Forest. Applied Soil Ecology 35: 340-355.

Olson JS. 1963. Energy storage and balance of producers and decomposers in ecological systems. Ecology 44: 322-331.

Ordoñez JAB, BHJ de Jong, F García-Oliva, FL Aviña, JV Pérez, G Guerrero, RD Martínez, O Masera. 2008. Carbon content in vegetation, litter, and soil under 10 different land-use and land-cover classes in the Central Highlands of Michoacan, Mexico. Forest Ecology and Management 255: 2074-2084.

Piene H, K van Cleve. 1978. Weight loss of litter and cellulose bags in a thinned white spruce forest in interior Alaska. $\mathrm{Ca}$ nadian Journal of Forest Research 8: 42-46.

Robertson PG, DC Coleman, CS Bledsoe, P Sollins. 1999. Standard soil methods for long-term ecological research (LTER). New York, USA. University Press. 465 p.
Sokal RR, FJ Rohlf. 1995. Biometry. New York, USA. Freeman and Company. 887 p.

StatSoft. 2000. Statistica ver. 6.0. for Windows. Computer program manual. Tulsa, USA.

Vance ED, AC Brookes, DS Jenkinson. 1987. An extraction method for measuring soil microbial biomass C. Soil Biology and Biochemistry 19: 703-707.

Vázquez-Marrufo G, R Serrato-Flores, JT Frías-Hernández, LA Jiménez-Magdaleno, V Olalde-Portugal. 2003. Microsite soil changes associated with traditional charcoal production in Quercus temperate forest in central Mexico. Phyton 85-99.

Vesterdal L, M Dalsgaard, C Felby, K Raulund-Rasmussen, B Jørgensen. 1995. Effects of thinning and soil properties on accumulation of carbon, nitrogen and phosphorus in the forest floor of Norway spruce stands. Forest Ecology and Management 77: 1-10.

von Ende CN. 1993. Repeated measures analysis: growth and other time-dependent measures. In Scheiner SM, J Gurevitch eds. Design and analysis of ecological experiments. New York, USA. Chapman and Hall. p. 113-137.

World Bank. 1995. Mexico Resource conservation and forest sector review. Natural Resources and Rural Poverty Operations Division Country Department II Latin America and the Caribbean Regional Office. Washington, DC, USA. World Bank. 183 p. 